Dan D. Y. Shapira

Ramat Gan

\title{
ICONOCLASTS AND KHAZARS, A NOTE
}

The date of the Khazar conversion to Judaism has been a matter of debate for a long time. ${ }^{1}$ Now we can date the conversion more or less precisely, for recently Khazar dirhams minted in 837-838, found in Sweden, which bear the Arabic inscription la Ilâha illâ-LLâh wa Mûsâ rasûlu ALLâh ("there is no god but God, and Moses is his messenger," instead of wa Muhammada rasûlu ALLâh, "and Muhammad is his messenger") and a tamğa, intended for circulation in the Caliphate and proclaiming the Biblical identity of the Khazars, ${ }^{2}$ assure that the conversion to Judaism took place not later than the first half of the ninth century. This disconnects the date of the conversion with the mission of the Thessalonica / Solun' brothers (861). ${ }^{3}$

However, a Byzantine Iconoclast dimension of the Khazar conversion to Judaism should be considered. ${ }^{4}$ Emperor Leo III the Isaurian (r. 717-741) had special connections with the Khazars throughout almost all of his career, beginning with his service under Justinian II (who had a Khazar wife) starting in 705 and his mission to Lazica, in order to forge a coalition against al-Walîd I; while an Emperor, he fought the

(1) For the survey of the previous views and a new dating, see P. B. Golden, The Conversion of the Khazars to Judaism, in: H. Ben-Shammai, P. B. Golden, A. RonÁ-Tas (eds.), The World of the Khazars: New Perspectives. Selected Papers from the Jerusalem 1999 International Khazar Colloquium (Leiden: Brill, 2007) 123-162.

(2) R. K. Kovalev, What Does Historical Numismatics Suggest About the Monetary History of Khazaria in the Ninth Century? - Question Revisited, AEMA 13 (2004) 97-129; IDEM, Creating Khazar Identity through Coins: The Special Issue Dirhams of 837/8, in: F. CurTA (ed.), East Central Europe in the Early Middle Ages (Ann Arbor, 2005) 220-253.

(3) As reconstructed in C. Zuckerman, On the Date of the Khazars' Conversion to Judaism and the Chronology of the Kings of the Rus' Oleg and Igor. A Study of the Anonymous Khazar Letter from the Genizah of Cairo, RÉB 53 (1995) 237-270. See also: D. D. Y. ShapiRa, Notes on Early Jewish History in Eastern and Central Europe: The Rus', Khazar and Bulgar Dimensions, AEMA 16 (2006-2007) forthcoming; see also J. HowARD-Johnston, Byzantine Sources for Khazar History, in: Ben-Shammai, Golden, Roné-Tas, The World of the Khazars..., 163-194; C. Zuckerman, The Khazars and Byzantium - The First Encounter, in: Ben-Shammai, Golden, Roná-Tas, The World of the Khazars..., 399-432.

(4) I am grateful to Kassia Senina, who drew my attention to this aspect. 
Arabs as an ally of the Khazar Qağan. Leo initiated conversions of Jews and heretics in 722 and Iconoclasm in 726-729, apparently aiming, i.a., both to attract the forcibly converted Jews to a non-image-worshipping form of Christianity and being influenced by the military successes of the Muslims who did not worship images. ${ }^{5}$ During the period of 730 780 (corresponding to the first Iconoclastic Period in Byzantium), many Iconodule monks found themselves in areas beyond Byzantium on the fringes of the Empire, including Georgia, Khazaria and the Crimea; as for the Jews, they may have fled following the forced conversion of 722. Following the great Khazar invasion into the lands of the Khalifate and their victories at Ardabîl, Diyâr Bakr and Mosul (730), ${ }^{6}$ Leo chose

(5) On the possible impact of Islam on Byzantine Iconoclasm, see P. Crone, Islam, Judeo-Christianity and Byzantine Iconoclasm, Jerusalem Studies in Arabic and Islam 2 (1980) 59-95. On the Jews of the Empire, see J. STARr, Jews in the Byzantine Empire 641-1204 (Athens, 1939); S. B. Bowman, The Jews of Byzantium, 1204-1453 (Tuscaloosa, AL: The University of Alabama Press, 1985); see also D. ОвоLеnsкy, The Byzantine Commonwealth: Eastern Europe, 500-1453 (London: Weidenfeld and Nicolson, 1971; Crestwood, NY: St. Vladimir's Seminary Press, 1982). Islam and Iconoclasm were frequently seen by the "Orthodox" as two similar forces, see D. SAHAs, The Arab Character of the Christian disputation with Islam. The case of John of Damascus (ca. 655 - ca. 749), in: B. Lewis, F. Niewöhner, O. Harrassowitz (Hrsg.), Religionsgespräche im Mittelalter (Wiesbaden, 1992) 185-205, p. 192.

(6) It is curious that more than two centuries later, the battle of Ardabil (730) was seen by the Khazar king as a turning point in the conversion to Judaism. According to the Long Version of the Reply of King Joseph sent to Hisdai ibn Shaprut in Cordoba, Spain, after Bulan and the Khazars converted 340 (!) years ago, God spoke to Bulan and ordered him to build a temple in the name of God to dwell therein; Bulan answered that he had no silver and gold, then God spoke to Bulan ordering him to be strong and firm and to go with all his army to the path of Dar-i Alân (Darial passage) to the earth of Ardewil (Ardabîl), where God had prepared for Bulan two treasures, one full of silver and one full of gold; Bulan did as he was told (albeit the Arab sources name the commander of the 730 invasion Barjik, the son of the Qağan), waged many wars and destroyed the city, taking much booty; he sanctified this booty / dedicated it to God and built from this booty the tabernacle (ohel), the ark (aron), the menorah, the table, the altars and the holy vessels, which, by the mercy of $\mathrm{H}^{\prime}$ and by the strength of Shaddai (note the correct distribution of the aspects of the mercy and power between two names of God used), are still held and kept with the author of the Reply, King Joseph. It was thereafter that the King of Edom (Rome, Byzantium) and the King of the Ishmaelites sent their ambassadors to the Khazars and a religious dispute followed, in which a Rabbi won. The chronology and the sequence of events are heavily distorted here, and no mention is made 
for his son and co-ruler, Constantine V (s.c. Copronymus, r. 718-775), ${ }^{7}$ a Khazar wife, daughter of the Qağan; originally named Tzitzak, ${ }^{8}$ she was baptized as Irene in 732. Some five years later, after having been defeated on the shores of the Volga by Marwân ibn Muhammad, her father (or brother?) forcibly accepted Islam for a short while, certainly not longer than until 746 or even earlier. Leo's victory over the forces of Hishâm ibn Abd al-Malik at Akroinon in 740, together with that of Charles Martel in 732 at Poitiers / Tours and the Khazar stand in 737, stopped the Arab advance into Europe, and Constantine, together with his Khazar relatives and allies, went on offensive against the Arabs in 746-752 and against the Bulgars, in 754-775. ${ }^{9}$ Tzitzak-Irene bore Constanine V one son, Leo IV the Khazar (co-ruler of his father from 751, r. 775-780). His death marked the end of the First Iconoclastic Period, and it was about the end of the First Iconoclastic Period that Muslim Abo of Tbilisi was able to convert to Christianity in the midst of shamanistic Täyri-worshipping Khazars. In the description of Khazar ways of life about 780 as found in Abo's Vita are the following observations: the "Khazars Sons of Magog" were Mongoloid (sašinel p'irita, "with horrible faces"), pagan ("having no religious law"), blood-eating and savage ( $k^{\prime} a c$ velur). However, there is no bias in this description; they worshipped the Creator (šemokmedi), the Turkic God of the Heavens Tärri, and there is no word about their Judaism. ${ }^{10}$

of a conversion to Islam in 737. The Hebrew text and Russian translation are in: П. К. Коковцов, Еврейско-хазарскал переписка в Х веке (Денинград, 1932).

(7) Admonished at length by Constantine Porphyrogennetos in chapter 13 of the De Administrando Imperio (Gy. Moravcsik (ed.), R. J. H. Jenkins (trans.), Constantine Porphyrogenitus, De administrando imperio, rev. ed., (Washington, D.C.: Dumbarton Oaks Center for Byzantine Studies, 1967) (CFHB) for his Khazar and Iconoclast connections.

(8) The name is generally explained as Turkic *čiček, "flower;" some explain it as a Hebrew word for the fringes attached to the ritual shawl.

(9) On Bulgaria and Byzantium, see R. Browning, Byzantium and Bulgaria (London, 1975), and ОвоLеnsку, The Byzantine Commonwealth...

(10) Text: I. V. Abuladze [Abulaje] (ed.), Jveli kartuli agiograp'iuli literaturis jeglebi [Monuments of the Old Georgian Hagiographic Literature] (Tbilisi, 1964) I, 46-81; studies and translations: K. Schultze, Das Martyrium des heiligen Abo von Tiflis, Texte und Untersuchungen zur Geschichte der Altchristlichen Literatur, NF 13.4 (1905) 4-41; P. Peeters, Les Khazars dans la Passion de S. Abo de Tiflis, AB 52.1-2 (1934) 21-56; H. GréGoIre, La vérité sur le Judaïsme des Khazars, Byzantion 9 (1934) 484-488 (review of the previous item); D. M. LANG, Lives and Legends of the Georgian Saints (London, 1956) 115-133; 
Emperor Leo V the Armenian initiated the Second Iconoclastic Period in Byzantium (815-842) after a series of humiliating defeats at the hands of the Bulgarian Khan Krum, ${ }^{11}$ and after a group of soldiers broke into the imperial mausoleum, opened the sarcophagus of Con-

M. Bíró, Abo's Georgian Vita, Acta Orientalia Academiae Scientiarum Hungariae, 31 (2) (1977) 247-260; D. D. Y. ShapIRA, Armenian and Georgian Sources on the Khazars: A Re-Evaluation, in: Ben-Shammai, Golden, RonÁ-Tas, The World of the Khazars..., 307-352 (347-349).

There is not a word about Khazar Judaism in the vita of St. John of Gothia from the Crimea, who led a rebellion against the Khazars who captured the Gothic fortress of Doros in 786/7, well after the end of the First Iconoclast Period. John spent some time in the Khazar prison at Phoullae; he died on 26.06.791, shortly after the Khazar ruler, who had persecuted the saint, was killed in a revolt; see Acta Sanctorum, Junii Tomus, VII, 167-171; В. Г. ВАсИльевСКИЙ, Житие Иоанна Готского, in: Труды, т. 2, вып. 2 (Санкт-Петербург, 1912) 396-400 = Житие Иоанна Готского, Русско-византийские отрывки VII, Журнал Министерства Народного Просвещения (январь 1878); В. Мошин, Eparxia Gotthias в Хазарии в XIII в., in: Tpуды IV съезда русских академических организациий заграницей, т. 1 (Белград, 1929) 149-156; on the Crimean Goths see A. A. Vasiliev, The Goths in the Crimea (Cambridge, MA: The Mediaeval Academy of America, 1936); for a new evaluation of the linguistic evidence for allegedly Gothic speech in the Ottoman Crimea (first noted in Augerius Gislenius Busbequius, De legatione Turcicae epistolae quatuor ... (Paris, 1589)), see M. Stearns, Crimean Gothic. Analysis and Etymology of the Corpus (Stanford: Anma Libri, 1978) (Studia Linguistica et Philologica, 6); on a forged Byzantine text from the Crimea, see I. ŠEvČENKo, The Date and Author of the So-Called Fragments of Toparcha Gothicus, in: IDEm, Byzantium and the Slavs (Cambridge, MA: Harvard University, 1991) 353-478; on some aspects of Khazar-Byzantine interaction in the Crimea, see Th. S. Noonan, The Khazar-Byzantine World of the Crimea in the Early Middle Ages: The Religious Dimension, AEMA 10 (1998-1999) 207-230.

Both Poullae and Doros have been identified as Mangup; other identifications include Eski-Kermen for Doros and Qarasubazar / Belogorsk for Phoullae, etc. In the early 1840s, Avraham Firkowicz forged a series of marginalia and colophons; in a couple of them mentions were made of the Khazars being Jewish in 786/7, while "liberating" Dori / Doros. Firkowicz took the date from the Vita of St. John of Gothia. New evidence for these texts as being forgeries made by Firkowicz is to be found in Д. ШАпиРА, Нынешнее состояние ряда приписок и колофонов на библейских рукописей из Первого Собрания А. С. Фирковича, in: Материаль Одиннадиатой Ежегодной Международной Междисцุиплинарной Конференциии по Иудаике. Ч. 1. Сәфер 16 (Москва, 2004) 102-130.

(11) On aspects of the traditional Khazar-Bulgar rivalry and their role in the Khazar conversion, see D. ShapiRa, Bulgar-Khazar Rivalry: Notes on Ethnical Historio-Psychology, in: Хазарский Альманах, vol. 1 (Proceedings of the Third International Khazar Colloquium) (Харьков, 2002) 214-224; IDEм, Notes 
stantine $\mathrm{V}$ (the husband of Tzitzak-Irene), and implored him to return and save the empire; the successor of Leo V, Michael II the Amorian, or Psellos (r. 820-829; sometimes described - wrongly - as of Judeo-Christian background ${ }^{12}$ ), was an Iconoclast, who in 824 even lamented image veneration in a letter to the Carolingian emperor Louis the Pious; and it was during this Second Iconoclastic Period - when all three Monotheistic religions of the East shared Iconoclastic tendencies - that the Khazar elite converted to Judaism.

The Iconoclasm came to an end during the reign of Michael III (r. 840-867), after the iconodule Methodius was appointed the Patriarch of Constantinople in 843. Michael III was successful in waging a war against the Abbasids in Anatolia and in 859 he laid siege on Samosata, but these efforts were brought to naught by the first recorded Rus' assault on Constantinople in June 860 (ironically, a century later, Syria and Palestine were spared from a successful Byzantine Crusade by a Svjatoslav-led Rus' invasion into Bulgaria). The actual text of the Russian Primary Chronicle containing dates begins with the phrase that it was in the days of Michael that the name of Rus' first became known, ${ }^{13}$ an echo of the remarks of Patriarch Photius in his Second Homily, $2 .{ }^{14}$ Guided by Photius, thought by some to have a Khazar ancestry, ${ }^{15}$ Michael exerted considerable effort in reconstructing church life and opening closed monasteries, reorganizing the imperial university and going on a project to christianize the Bulgars, Slavs and Khazars. This was the background for the mission of the Thessaloniki (Solun') brothers Cyrill and Methodius, sent to the Khazar Qağan in 861 in order to stop the recent expansion of Judaism in Khazaria and to gain the Qağan's support against possible attacks by Rus'. It is clear

on Early Jewish History in Eastern and Central Europe: The Rus', Khazar and Bulgar Dimensions, AEMA 16 (2006-2007) forthcoming.

(12) On the "heresy" on his background, see J. StarR, An Eastern Christian Sect: The Athinganoi: To the Memory of Prof. Andreas Michael Andreades (1877-1935), The Harvard Theological Review 29.2 (1936) 93-106.

(13) “Въ лЂто 6360 индикта 15 день наченшю Михаилу царствовати нача ся прозывати Руска земля о семь бо увъдахомъ яко при семь цари приходиша Русь на Царьгородъ яко же пишется в льтописаньи гречестьмь." The date given by the editor of the Chronicle (852CE) is notoriously wrong, as are almost all the dates prior to the rule of St. Vladimir.

(14) Cf. C. Mango (trans., intro., and comm.), The Homilies of Photius, Patriarch of Constantinople (Cambridge, MA: Harvard University Press, 1958).

(15) Cf. D. M. Dunlop, History of the Jewish Khazars (Princeton, NJ: Princeton University Press, 1954) 194. 
that there was some connection between the end of the Iconoclasm and the sending of the brothers on their Khazar mission. The Vita of St. Cyril ${ }^{16}$ does not say implicitly that the Khazars were already Judaized, nevertheless, in the religious disputation described in this text - one of the many debates imprinted on the memory of generations of Christians, Jews, and Muslims of Western Eurasia ${ }^{17}$ - the Qağan said to the brothers, among other things, that "we all speak of the same things: the only difference between us is that you worship the Trinity, and we, the One God, as we have been taught by our books." This conciliatory tone is reminiscent of the well-known tolerance in questions of religion displayed by the Khazars after their Judaization, although the mention

(16) P. J. ŠAfarik, Památky drevního pismenictví Juhoslovanưv v Praze, 1851, 1873; F. MiкLоsich, Die Legende vom heiligen Cyrillus (Wien 1870); А. Е. БАлАН, Кирил и Методи. 1. Свезка пьрва: Житие на Кирила и Методия и похвални тем слова (София, 1920); Б. Н. Флоря (intro, trans, and comm.), Сказания о начале славянской письменности (Москва, 1981); Ю. Трифонов, Константин Философ (св. Кирил) като царски пратеник при сарацини и хазари, in: Сборник в чест на проф. А. Милетич (София, 1933) 33-44; F. Dvorniк, Les legendes de Constantin et de Methode, vues de Byzance (Prague, 1933).

(17) For different account on the disputations, see Dunlor, History of the Jewish Khazars... 89-170 (chapters V and VI). In the mid-19th century, the Karaite-Jewish manuscript-hunter, Avraham Firkowicz, created the fortituous figure of a Jewish sage, who converted the Khazars, whom he called "Isaac Sangari." Strange enough, even Avraham Harkavy believed, at least for a while, in the reality of this "Isaac Sangari," see А. ГАРКАвИ, Заметка о Сангари, in: В. А. БИльБАСов, Кирилх и Мефодий, т. 2 (Санкт-Петербург, 1871) 376-383. On the "Sangari's tomb" and other Firkowicz' forgeries, see D. SHapira, Yitshaq Sangari, Sangarit, Bezalel Stern, and Avraham Firkowicz: Notes on Two Forged Inscriptions, AEMA 12 (2002-2003) 223-260); a Russian version in: Mamepuavbl по археологии, истории и этнографии Таврии 10 (Симферополь, 2003) 535-555; another slightly different Russian version: Ицхак Сангари, Сангарит, Бецалель Штерн и Авраам Фиркович: история двух поддельных надписей [Yitshaq Sangari, Sangarit, Bezalel Stern and Avraham Firkowicz: The History of Two Forged Inscriptions], Параллели הקבלות, 2-3 (Москва, 2003) 363-388; on the forged Hebrew document said to be telling the story of the religious dispute in Kiev, based in fact on the Russian Primary Chronicle s.a. 986, see D. D. Y. SHAPIRA, Remarks on Avraham Firkowicz and the Hebrew Mejelis "Document," Acta Orientalia Academiae Scientiarum Hungaricae 59.2 (2006) 131-180; a fuller version: Ibid., The Mejelis "Document" and Tapani Harvianen: On Scholarship, Firkowicz and Forgeries, in: Mehmet Alpargu and Yücel Öztürk (eds.), Omeljan Pritsak Armăganı [A Tribute to Omeljan Pritsak] (Sakarya, 2007) 303-393; on the marginalia, containing pseudo-historical information on the Khazars, forged by A. Firkowicz, see my paper mentioned at the end of note 10. 
of "teaching by books" sounds strange coming from a nomadic Qağan in 861 and brings to mind the motifs of the "cave of books" in Sefer Kozari of Yehuda Halevi and the finding of Jewish books in a cave in the Letter of King Joseph, both still insufficiently explained. On the other hand, the Khazars boast before the missionary brothers of carrying their wisdom in their bellies, unlike the Greeks who find their wisdom in books. Finally, the Khazars pride themselves on the fact that all power in their country reposes in a single family, unlike the Greeks with their constantly changing dynasties. Moreover, the description of the mission in the Qağan's capital suggests that a certain advisor to the Qağan already enjoyed a very different status from all other subjects; it is not hard to identify this advisor with the bek, who would soon eclipse the Qağan. All this suggests that the rulers of Khazaria had already been Judaized, at least, to some extent.

Probably this silence about the Judaism of the Khazars in all the Byzantine literature, including the Vita of St. Cyril, was due to embarrassment over the fact that the brothers failed exactly when the veneration of icons and the restoration of Orthodoxy had been achieved. Although the religious part of their mission was a failure, their next mission in 863 secured the conversion of Great Moravia / Slavic Pannonia, where the brothers devised a Slavic alphabet (Glagolitic, not "Cyrillic") and established a school of translation. About this time Khan Boris I of Bulgaria converted, too, first to the Roman rite, and then to the Byzantine one, after Michael III and the Caesar Bardas invaded his country in $864 .{ }^{18}$

So, it seems that there was at least some overlapping of the KhazarByzantine entente, directed against the Khalifate, with the periods of Iconoclam in Byzantium. However, further Byzantinicist research in this direction is a desideratum.

(18) The manoeuvrings of Boris / Bogoris / Michael I of Bulgaria between Constantinople and Rome provoked the so-called Photian Schism. About 864, a Benedictine monk in Corvei, Westphalia, called Christian Druthmar, or Christian of Stavelot, wrote in his commentary on Matthew 24:14: "At the present time we know of no nation under the heavens where Christians do not live. For [Christians are even found] in the lands of Gog and Magog who are a Hunnic race and are called Gazari ... are circumcized and observing the whole of Judaism (quae sunt gentes Hunnorum, quae ab eis Gazari vocantur... circumcisa est et omnem Judaismum observat). The Bulgars, however, who are of the same seven tribes [as the Khazars], are now becoming baptized" (Expositio in Matthaeum Evangelistam, in: PL, ser. 2, t. 106, col. 1456). 